\title{
PENGARUH MODEL PEMBELAJARAN POGIL BERBANTUAN PETA PIKIRAN TERHADAP HASIL BELAJAR IPA SISWA KELAS V SD
}

\author{
Ni Putu Yuliani \\ Jurusan Pendidikan Guru Sekolah Dasar Universitas Pendidikan Ganesha \\ E-mail: niputuyuliani466@yahoo.com \\ Gede Margunayasa \\ Jurusan Pendidikan Guru Sekolah Dasar Universitas Pendidikan Ganesha \\ E-mail: igede.margunayasa@undiksha.ac.id \\ Desak Putu Parmiti \\ Jurusan Pendidikan Guru Sekolah Dasar Universitas Pendidikan Ganesha \\ E-mail:dp-parmiti@undiksha.ac.id
}

\begin{abstract}
Abstrak
Penelitian ini bertujuan untuk mengetahui perbedaan hasil belajar IPA antara kelompok siswa yang dibelajarkan dengan model POGIL berbantuan peta pikiran dan kelompok siswa yang tidak dibelajarkan dengan model POGIL berbantuan peta pikiran. Penelitian eksperimen ini menggunakan rancangan penelitian non-equivalent post test only control group design. Populasi penelitian adalah seluruh siswa kelas V SD di Gugus II Kecamatan Banjar Tahun Pelajaran 2016/2017. Sampel diambil dengan teknik random sampling. Data yang telah dikumpulkan dianalisis dengan statistik deskriptif dan uji $\mathrm{t}$ independent. Hasil penelitian menunjukkan bahwa: (1) hasil belajar IPA siswa setelah diberikan perlakuan model POGIL berbantuan peta pikiran berada pada kategori sangat tinggi dengan rata-rata 25,21; (2) hasil belajar IPA siswa yang tidak diberikan perlakuan model POGIL berbantuan peta pikiran berada pada kategori tinggi dengan rata-rata 18,58; (3) terdapat perbedaan yang signifikan hasil belajar IPA antara kelompok siswa yang dibelajarkan dengan model POGIL berbantuan peta pikiran dan kelompok siswa yang tidak dibelajarkan dengan model POGIL berbantuan peta pikiran. Hasil perhitungan uji-t independent diperoleh thitung $=6,7$ dan $t_{\text {tabel }}=2,002$ ( $t_{\text {hitung }}>t_{\text {tabel }}$ ) pada taraf signifikansi 5\%. Dengan demikian, model POGIL berbantuan peta pikiran berpengaruh terhadap hasil belajar IPA siswa.
\end{abstract}

Kata kunci: hasil belajar IPA, model Process Oriented Guided Inquiry Learning, peta pikiran

\begin{abstract}
This study was aimed to identify the difference of the sciences learning outcome between a group of students who learnt by using POGIL model with mind mapping and the other group of students who did not learnt by using POGIL model with mind mapping. This experimental study was designed in non-equivalent post-test only control group design. The population of the study was all of the fifth grade students belonging to Cluster II of Banjar Sub-district in the academic year of 2016/2017. Samples were taken by random sampling technique. The obtained data were analyzed by using descriptive statistics and t-test. The result shows that (1) the sciences learning outcome of the students after being given POGIL model treatment with mind mapping is in the very high category with an average of 25.21 , (2) the sciences learning outcome of the students that were not given POGIL model treatment with mind mapping is in the high category with an average of 18.58 , (3) there are significant differences of the sciences learning outcome between a group of students who learn by using POGIL model with mind mapping and the other group of students who do not learn by using POGIL model with mind mapping. The result of $\mathrm{t}$-test shows that $\mathrm{t}_{\text {hitung }}=6,7$ and $\mathrm{t}_{\text {tabel }}=2,002$ ( $\mathrm{t}_{\text {hitung }}>\mathrm{t}_{\text {tabel }}$ ) on the significant level 5\%. Thus, POGIL learning model affects student's sciences learning outcome.
\end{abstract}

Keywords: mind mapping, Process Oriented Guided Inquiry Learning models, sciences learning outcome

\section{Pendahuluan}

Saat ini Indonesia sedang memasuki era globaliasasi. Dalam era globalisasi setiap individu dituntut untuk mempersiapkan Sumber Daya Manusia (SDM) yang berkualitas terutama di bidang Ilmu Pengetahuan dan Teknologi (IPTEK). SDM yang berkualitas dapat dipersiapkan melalui pendidikan yang memadai. Hal ini sesuai dengan pendapat dari Wiratma (2010:16), "Pendidikan dapat dijadikan sebagai sarana untuk melahirkan SDM yang berkualitas."

Melihat pentingnya peran pendidikan terhadap kualitas SDM, maka pemerintah melakukan berbagai upaya untuk meningkatkan mutu pendidikan. Upaya yang dilakukan oleh pemerintah ternyata belum membuahkan hasil yang optimal dalam meningkatkan pendidikan di Indonesia. Kondisi pendidikan Indonesia saat ini sedang dalam kondisi gawat darurat (Kemdikbud, 2014). Berdasarkan pemetaan pendidikan pada mata 
pelajaran Matematika dan IPA dari Trends in International Mathematics and Science Studies (TIMSS) dari tahun 2011, Indonesia berada pada peringkat 40 dari 42 negara. Begitu juga kajian yang dibuat oleh Programme for International Student Assesment (PISA) untuk mengukur pengetahuan siswa pada tiga kompetensi dasar yaitu membaca, matematika dan sains tahun 2016 capaian PISA Indonesia sedikit meningkat namun capaian masih di bawah rerata negara-negara Organisation for Economic Cooperation and Development (Kemdikbud, 2016). Berdasarkan studi PISA dan TIMSS tersebut, diperlukan upaya untuk meningkatkan kualitas pendidikan IPA di Indonesia.

IPA merupakan salah satu mata pelajaran pokok dalam kurikulum pendidikan di Indonesia, termasuk pada jenjang sekolah dasar (Susanto, 2014). Dalam membelajarkan IPA seorang pendidik harus mengetahui terlebih dahulu hakikat IPA itu sendiri. IPA memiliki tiga komponen yaitu produk ilmiah, proses ilmiah, dan sikap ilmiah (Santyasa, 2005). Oleh karena itu, dalam pembelajaran IPA haruslah terkandung ketiga komponen tersebut. Agar pembelajaran IPA dapat mencakup ketiga komponen IPA maka dalam pembelajaran IPA di sekolah dasar hendaknya dilakukan penyelidikan-penyelidikan sederhana yang berbasis proses dan bukan hafalan terhadap kumpulan konsep IPA. Melalui kegiatan penyelidikan sederhana siswa dapat membangun sendiri pengetahuan di dalam benaknya. Hal ini sesuai dengan teori konstruktivisme yang memandang bahwa untuk dapat memahami konsep IPA, maka keaktifan siswa untuk membangun pengetahuannya sendiri sangat diperlukan (Trianto, 2007).

Berdasarkan kenyataan lapangan ketika dilakukan wawancara, observasi, dan studi dokumentasi pada tanggal 11 Januari 2017 sampai dengan 12 Januari 2017 didapatkan hasil sebagai berikut. Berdasarkan hasil wawancara dengan guru mata pelajaran IPA, diperoleh informasi bahwa mata pelajaran IPA di Gugus II Kecamatan Banjar memiliki hasil belajar rendah. Rendahnya hasil belajar siswa dipengaruhi oleh kurangnya pengetahuan guru tentang model pembelajaran yang berpusat kepada siswa (student center). Sebagian besar guru beranggapan bahwa metode ceramah merupakan metode pembelajaran yang paling praktis, mudah, dan efisien. Guru beranggapan bahwa siswa telah menguasai meteri pelajaran seperti apa yang telah dikuasai guru.

Berdasarkan hasil observasi, diperoleh fakta pada pelaksanaan pembelajaran IPA di kelas yaitu sebagai berikut. (1) Siswa terlihat mengalami kebosanan yang ditunjukkan dengan terdapat beberapa siswa yang pandangannya tidak fokus, mengobrol dan bermain dengan teman sebangku ketika materi pelajaran IPA dijelaskan oleh guru. (2) Kemampuan siswa dalam proses ilmiah dan sikap ilmiah pada saat percobaan sangat kurang. (3) Siswa tidak berperan aktif dalam mengonstruksi pengetahuannya dan hanya diarahkan untuk menghafal materi pelajaran sehingga sebagian besar siswa tidak memahami materi yang disampaikan oleh guru. (4) Siswa jarang mendapat kesempatan untuk mengimplementasikan penemuan konsep yang telah diperoleh sehingga pengetahuan yang didapatkan siswa menjadi kurang bermakna. (5) Daya ingat siswa terhadap materi pelajaran IPA cenderung tidak lama dan pengetahuan yang didapat siswa tidak terorganisir dengan baik.

Berdasarkan hasil pencatatan dokumen tentang nilai mata pelajaran IPA menunjukkan bahwa hasil belajar mata pelajaran IPA siswa kelas V pada semester I tahun pelajaran 2016/2017 masih rendah. Hal ini terlihat dari nilai Ulangan Akhir Semester (UAS) siswa pada mata pelajaran IPA di Gugus II Kecamatan Banjar masih banyak yang dibawah Kriteria Ketuntasan Minimal (KKM). sejumlah 80 orang siswa dari 157 orang siswa belum mencapai KKM. Sedangkan jika dilihat dari nilai rata-rata kelas pada masing-masing SD berkisar dari 66,9 sampai 73,3 berada pada kategori cukup.

Temuan rendahnya hasil belajar IPA menunjukkan bahwa perlu adanya upaya memperbaiki proses pembelajaran IPA. Upaya yang dapat dilakukan oleh guru untuk memperbaiki proses pembelajaran IPA adalah dengan menggunakan berbagai pendekatan, strategi, model, media, dan metode dengan tepat sesuai dengan permasalahan yang ada. Salah satu alternatif yang dipandang mampu meningkatkan hasil belajar IPA adalah pembelajaran dengan model POGIL. POGIL merupakan singkatan dari Process Oriented Guided Inquiry Learning. Model pembelajaran POGIL merupakan salah satu model pembelajaran inkuiri yaitu inkuiri terbimbing yang berbasis proses. Inquiry merupakan proses pembelajaran dimana siswa mengeksplorasi seluruh sumber daya yang ada untuk memperoleh pemahaman (Brickman, 2009).

Warsono dan Hariyanto (2014) menyatakan bahwa pembelajaran POGIL menerapkan suatu metode yang berlandaskan pembelajaran berbasis siswa (student-centered) dan suatu struktur yang secara konsisten menyajikan bagaimana cara siswa belajar dan mencapai hasil pembelajarannya. Model POGIL merupakan model pembelajaran yang berdasar pada teori konstruktivisme. Seperti yang diungkapkan oleh Farrell et al., dan Spencer (dalam Simonson dan Shadle, 2013) bahwa pembelajaran ini berbasis pada penemuan ilmu pengetahuan yang diperoleh dari serangkaian proses penyelidikan.

Hale dan Mullen (2009) mengatakan bahwa tujuan dari rancangan pengajaran (POGIL) ini adalah: (1) untuk mengembangkan penguasan konten/isi; dan (2) untuk mengembangkan keterampilan proses-orientasi seperti pemecahan masalah, berpikir kritis dan analitis, dan komunikasi lisan dan tulisan. Kegiatan model POGIL dibangun di atas kerangka siklus pembelajaran (learning cycle), sebuah pendekatan yang terbukti efektif dalam pembelajaran IPA (Karplus et al., dalam Simonson dan Shadle, 2013). Barthlow (2011) 
menyatakan bahwa siklus pembelajaran terdiri atas tiga tahap, yaitu eksplorasi, penemuan konsep, dan aplikasi. Setelah melakukan pembelajaran POGIL siswa akan memperoleh konsep-konsep dalam materi pelajaran. Peta pikiran merupakan salah satu cara untuk mengorganisasikan konsep-konsep yang telah dipelajari oleh siswa.

Peta pikiran merupakan suatu teknik mengorganisasikan sebuah informasi yang didapat ke dalam bentuk gambar, simbol, atau warna secara kreatif dan efektif dengan tujuan untuk memudahkan pemahaman si penerima informasi dan mengingatnya lebih lama (Buzan, 2007). Peta pikiran adalah cara untuk mengasimilasikan konsep-konsep yang telah dipelajari oleh siswa (Wardani, 2015). Pada pembelajaran POGIL peta pikiran akan digunakan di akhir pembelajaran untuk mereview apa yang telah diketahui siswa. Kegiatan ini dapat membuat pengetahuan yang telah didapat oleh siswa menjadi lebih terstruktur.

Berdasarkan uraian di atas, dipandang perlu dilakukan penelitian dengan tujuan untuk mengetahui perbedaan hasil belajar IPA antara kelompok siswa yang dibelajarkan dengan model pembelajaran POGIL berbantuan peta pikiran dan kelompok siswa yang tidak dibelajarkan dengan model pembelajaran POGIL berbantuan peta pikiran pada siswa kelas V SD di Gugus II Kecamatan Banjar Tahun Pelajaran 2016/2017.

\section{Metode Penelitian}

Penelitian ini merupakan eksperimen semu dan menggunakan rancangan penelitian non-equivalent post test only control group design. Populasi penelitian adalah seluruh siswa kelas V SD di Gugus II Kecamatan Banjar Tahun Pelajaran 2016/2017 sebanyak 157 siswa. Sampel diambil dengan teknik random sampling dengan banyak 59 siswa. Sebelum menentukan sampel penelitian, populasi tersebut diuji kesetaraannya berdasarkan nilai UAS IPA semester ganjil dengan uji Anava Satu Jalur. Berdasarkan uji kesetaraan yang dilakukan, diketahui bahwa nilai hasil belajar IPA siswa di gugus tersebut telah setara.

Kelas yang diikutkan dalam pengundian adalah kelas yang memiliki hasil belajar IPA setara. Hasil uji kesetaraan menunjukkan bahwa kemampuan IPA siswa kelas V SD di Gugus II Kecamatan Banjar adalah setara, sehingga seluruh kelas dalam populasi disertakan dalam pengundian. Berdasarkan hasil pengundian, sampel penelitian ini adalah siswa kelas V di SD Negeri 2 Tigawasa sebagai kelompok eksperimen dengan banyak siswa 28 orang dan siswa kelas V di SD Negeri 3 Tigawasa sebagai kelompok kontrol dengan banyak siswa 31 orang. Variabel dalam penelitian ini terdiri atas variabel bebas yaitu model pembelajaran dan variabel terikat yaitu hasil belajar IPA.

Data yang dikumpulkan pada penelitian ini adalah data hasil belajar IPA siswa kelas V sekolah dasar yang ada di Gugus II Kecamatan Banjar, Kabupaten Buleleng. Data hasil belajar IPA siswa pada penelitian ini dikumpulkan dengan menggunakan metode tes dan menggunakan satu jenis alat (instrumen) penelitian yaitu berupa tes pilihan ganda sebanyak 30 butir. Data yang dikumpulkan dianalisis dengan menggunakan analisis statistik deskriptif, analisis uji prasyarat dan uji hipotesis dengan menggunakan uji t independent.

\section{Hasil dan Pembahasan \\ Hasil Penelitian}

Pengukuran dilakukan setelah kelompok eksperimen diberikan perlakuan model pembelajaran POGIL berbantuan peta pikiran dan kelompok kontrol tidak diberikan perlakuan model pembelajaran POGIL berbantuan peta pikiran, sebanyak tujuh kali pertemuan dengan materi ajar yang sama. Analisis data dilakukan pada masing-masing kelas yaitu kelas eksperimen dan kelas kontrol. Adapun hasil analisis data statistik deskriptif disajikan pada Tabel 1.

Tabel 1. Analisis Data dengan Statistik Deskriptif

\begin{tabular}{ccc}
\hline Statistik & Kelompok Eksperimen & Kelompok Kontrol \\
\hline Mean & 25,21 & 18,58 \\
Median & 25,5 & 17,85 \\
Modus & 25,9 & 17,79 \\
Standar Deviasi & 3,69 & 3,9 \\
Varians & 13,60 & 15,21 \\
\hline
\end{tabular}

Pada kelompok siswa yang dibelajarkan dengan model POGIL berbantuan peta pikiran banyak siswa yang mendapat nilai rata-rata kelompok $(25,21)$ yaitu $32,14 \%$. Sedangkan yang mendapat nilai di bawah ratarata yaitu $28,57 \%$ dan yang mendapat nilai di atas rata-rata yaitu 39,29\%. Kategori rata-rata hitung data hasil belajar IPA kelompok siswa yang dibelajarkan dengan model POGIL berbantuan peta pikiran dapat diketahui dengan cara rata-rata hitung skor hasil belajar IPA dikonversikan ke dalam kategori skala lima menggunakan kriteria rata-rata idel (Mi) dan standar deviasi ideal (SDi). Rata-rata hitung data hasil belajar IPA kelompok kelompok siswa yang dibelajarkan dengan model POGIL berbantuan peta pikiran $(\mathrm{M}=25,21)$ berada pada rentang $22,50 \leq X \leq 30,00$. Jadi, rata-rata hitung data hasil belajar IPA kelompok siswa yang dibelajarkan 
dengan model POGIL berbantuan peta pikiran dikategorikan sangat tinggi. Berdasarkan data pada Tabel 1, data hasil belajar kelompok eksperimen disajikan dalam bentuk kurva polygon, seperti Gambar 1.

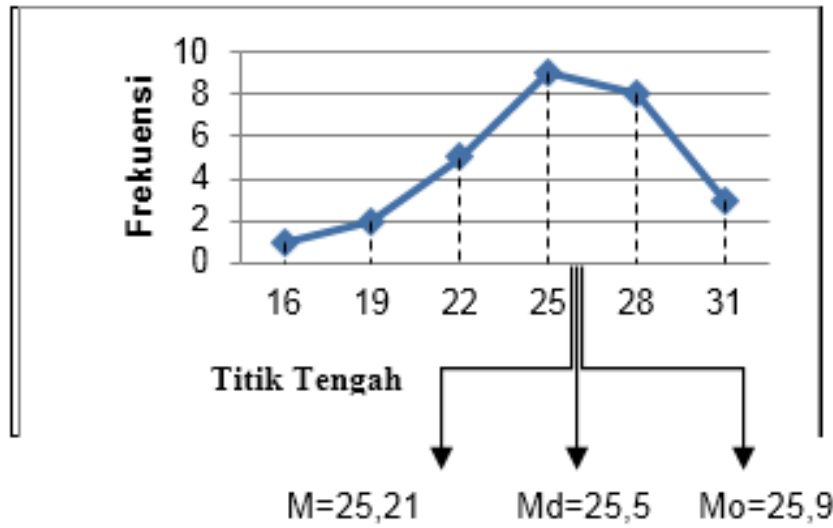

Gambar 1. Kurva Polygon Data Hasil Belajar IPA Siswa Kelompok Eksperimen

Berdasarkan kurva polygon data hasil belajar IPA kelompok siswa yang dibelajarkan dengan model POGIL berbantuan peta pikiran, dapat diketahui bahwa modus lebih besar dari median dan median lebih besar dari mean $(\mathrm{Mo}>\mathrm{Md}>\mathrm{M})$. Dengan demikian, kurva diatas adalah kurva juling negatif. Artinya, sebagian besar skor cenderung tinggi.

Sedangkan pada kelompok siswa yang tidak dibelajarkan dengan model POGIL berbantuan peta pikiran banyak siswa yang mendapat nilai sekitar rata-rata kelompok $(18,58)$ yaitu $32,26 \%$. Sedangkan yang mendapat nilai di bawah rata-rata yaitu $35,48 \%$ dan yang mendapat nilai di atas rata-rata yaitu $32,26, \%$. Kategori ratarata hitung data hasil belajar IPA kelompok siswa yang tidak dibelajarkan dengan model POGIL berbantuan peta pikiran dapat diketahui dengan cara rata-rata hitung skor hasil belajar IPA dikonversikan ke dalam kategori skala lima menggunakan kriteria rata-rata idel (Mi) dan standar deviasi ideal (SDi). Rata-rata hitung data hasil belajar IPA kelompok siswa yang tidak dibelajarkan dengan model POGIL berbantuan peta pikiran $(\mathrm{M}=18,58)$ berada pada rentang $17,50 \leq \mathrm{X}<22,50$. Jadi, rata-rata hitung data hasil belajar IPA kelompok siswa yang tidak dibelajarkan dengan model POGIL berbantuan peta pikiran dikategorikan tinggi. Data hasil belajar IPA siswa kelas kontrol disajikan pada Gambar 2.

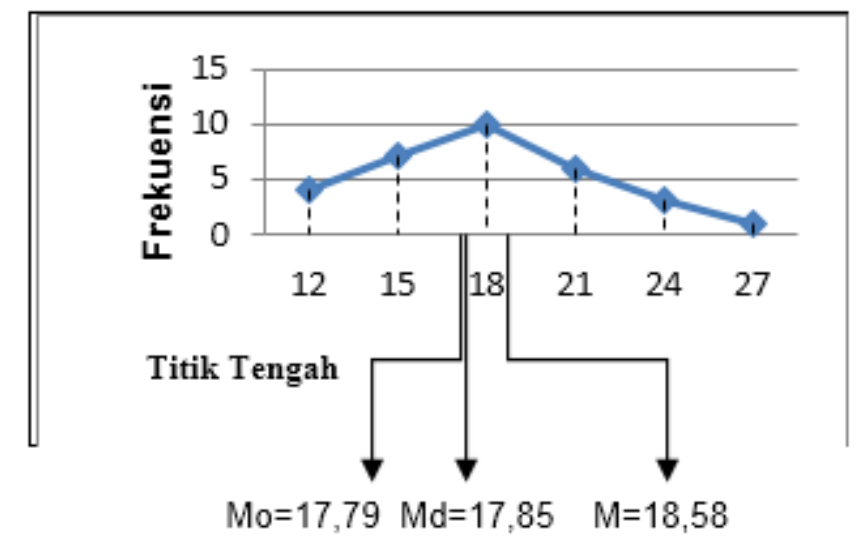

Gambar 2. Kurva Polygon Data Hasil Belajar IPA Siswa Kelompok Kontrol

Berdasarkan kurva polygon data hasil belajar IPA kelompok siswa yang tidak dibelajarkan dengan model POGIL berbantuan peta pikiran diatas, dapat diketahui bahwa modus lebih kecil dari median dan median lebih kecil dari mean $(\mathrm{Mo}<\mathrm{Md}<\mathrm{M})$. Dengan demikian, kurva diatas adalah kurva juling positif. Artinya, sebagian besar skor cenderung rendah.

Setelah melakukan analisis statistik deskriptif, selanjutnya dilakukan uji prasyarat untuk menguji hipotesis. Uji prasyarat yang dilakukan adalah uji normalitas sebaran data dan uji homogenitas varians. Uji normalitas sebaran data dengan teknik Chi-Square dilakukan terhadap dua jenis data, yaitu data hasil belajar IPA pada kelompok siswa yang dibelajarkan dengan model POGIL berbantuan peta pikiran dan data hasil belajar IPA pada kelompok siswa yang tidak dibelajarkan dengan model POGIL berbantuan peta pikiran. Hasil uji normalitas sebaran data hasil belajar IPA pada kelompok eksperimen menunjukkan harga Chi-Square hitung $\left(\chi^{2}\right.$ hitung) lebih kecil daripada harga Chi-Square tabel $\left(\chi^{2}\right.$ tabel $)$ yaitu $1,27<11,07$ pada taraf 
signifikansi 5\%, maka dapat disimpulkan bahwa hasil belajar IPA kelompok siswa yang dibelajarkan dengan model POGIL berbantuan peta pikiran berdistribusi normal. Data hasil belajar IPA pada kelompok kontrol menunjukkan harga Chi-Square hitung $\left(\chi^{2}\right.$ hitung) lebih kecil daripada harga Chi-Square tabel $\left(\chi^{2}\right.$ tabel) yaitu 5,22 < 11,07 pada taraf signifikansi 5\%, maka dapat disimpulkan bahwa hasil belajar IPA kelompok siswa yang tidak dibelajarkan dengan model POGIL berbantuan peta pikiran berdistribusi normal.

Selanjutnya, dilakukan uji homogenitas varians kelompok eksperimen dan kelompok kontrol. Uji homogenitas varians dilakukan menggunakan rumus uji Fisher (F). Kriteria pengujian tolak $\mathrm{H}_{0}$ jika $\mathrm{F}_{\text {hitung }} \geq$ $\mathrm{F}_{(\alpha)(v 1, v 2)}$. Uji dilakukan pada taraf signifikansi 5\% dengan derajat kebebasan pembilang $n_{1}-1$ dan derajat kebebasan penyebut yaitu $\mathrm{n}_{2}-1$. Berdasarkan uji homogenitas yang telah dilakukan pada data hasil belajar IPA kelompok siswa yang dibelajarkan dengan model POGIL berbantuan peta pikiran dan kelompok siswa yang tidak dibelajarkan dengan model POGIL berbantuan peta pikiran menunjukkan harga $\mathrm{F}_{\text {hitung }}<\mathrm{F}_{\text {tabel }}(1,09<$ 4,01) sehingga $\mathrm{H}_{0}$ yaitu variansi data sampel pada tiap kelompok tidak berbeda secara signifikan diterima. Jadi, variansi data hasil belajar IPA kelompok siswa yang dibelajarkan dengan model POGIL berbantuan peta pikiran dan kelompok siswa yang tidak dibelajarkan dengan model POGIL berbantuan peta pikiran adalah homogen.

Setelah diperoleh hasil analisis uji prasyarat dilanjutkan dengan uji hipotesis. Untuk mengetahui pengaruh model pembelajaran POGIL berbantuan peta pikiran terhadap hasil belajar IPA siswa, dilakukan pengujian terhadap hipotesis nol $\left(\mathrm{H}_{0}\right)$ dan hipotesis alternatif $\left(\mathrm{H}_{1}\right)$. Kedua hipotesis yang diajukan diuji dengan uji-t independent (tidak berkorelasi) dengan rumus polled varians.

Kriteria pengujian adalah tolak $\mathrm{H}_{0}$ jika $\mathrm{t}_{\text {hitung }}>\mathrm{t}_{\text {tabel, }}$, dimana $\mathrm{t}_{\text {tabel }}$ diperoleh dari tabel distribusi $t$ pada taraf signifikansi 5\% dengan derajat kebebasan $\mathrm{db}=\mathrm{n}_{1}+\mathrm{n}_{2}-2$. Berdasarkan hasil perhitungan uji-t sample independent, diperoleh $t_{\text {hitung }}$ adalah 6,7. Sedangkan $t_{\text {tabel }}$ pada taraf signifikansi $5 \%$ dan $\mathrm{db}=57$ adalah 2,002 . Hal ini berarti, $t_{\text {hitung }}$ lebih besar dari $t_{\text {tabel }}(6,7>2,002)$, sehingga $\mathrm{H}_{0}$ ditolak dan $\mathrm{H}_{1}$ diterima. Jadi terdapat perbedaan yang signifikan hasil belajar IPA antara kelompok siswa yang dibelajarkan dengan model pembelajaran POGIL berbantuan peta pikiran dan kelompok siswa yang tidak dibelajarkan dengan model pembelajaran POGIL berbantuan peta pikiran pada siswa kelas V SD di Gugus II Kecamatan Banjar Tahun Pelajaran 2016/2017.

\section{Pembahasan}

Berdasarkan deskripsi data hasil penelitian, hasil belajar IPA kelompok siswa yang dibelajarkan dengan model pembelajaran POGIL berbantuan peta pikiran lebih baik dibandingkan dengan kelompok siswa yang tidak dibelajarkan dengan model pembelajaran POGIL berbantuan peta pikiran. Selain itu, hasil pengujian hipotesis menunjukkan nilai $t_{\text {hitung }}$ lebih besar dari $t_{\text {tabel }}$ pada taraf signifikansi $5 \%$ yang artinya terdapat perbedaan yang signifikan hasil belajar IPA antara kelompok siswa yang dibelajarkan dengan model pembelajaran POGIL berbantuan peta pikiran dan kelompok siswa yang tidak dibelajarkan dengan model pembelajaran POGIL berbantuan peta pikiran pada siswa kelas V SD di Gugus II Kecamatan Banjar Tahun Pelajaran 2016/2017. Terdapat beberapa hal yang menyebabkan hasil belajar IPA kelompok siswa yang dibelajarkan dengan model POGIL berbantuan peta pikiran lebih baik dibandingkan dengan hasil belajar IPA kelompok siswa yang tidak dibelajarkan dengan model POGIL berbantuan peta pikiran yaitu sebagai berikut.

Pertama, pada siklus pembelajaran dengan model POGIL terdapat fase eksplorasi. Fase eksplorasi memberikan kesempatan kepada siswa untuk mencari tahu sendiri jawaban atas permasalahan yang diberikan melalui tim belajar dan aktivitas inkuiri terbimbing. Permasalahan tersebut dapat disajikan dalam bentuk serangkaian pertanyaan yang akan ditanggapi oleh siswa. Pertanyaan tersebut akan memandu siswa pada suatu proses untuk mengeksplorasi suatu tugas yang harus diselesaikan. Dalam fase eksplorasi ini, siswa berdiskusi bersama kelompok dan berusaha menjelaskan atau memahami bahan ajar, dengan cara mengemukakan, mengajukan pertanyaan dan menguji hipotesis. Pada fase ini siswa tidak menghadirkan konsep secara eksplisit. Siswa secara efektif dipandu dan didorong untuk mengeksplorasi, kemudian membuat kesimpulan dan membuat prediksi. Dengan demikian pada fase eksplorasi siswa aktif terlibat langsung dalam membangun pengetahuannya sehingga pemahaman siswa terhadap konsep IPA menjadi lebih baik. Hal ini sesuai dengan teori konstruktivisme yang memandang bahwa untuk dapat memahami konsep IPA, maka keaktifan siswa untuk membangun pengetahuannya sendiri sangat diperlukan (Trianto, 2007).

Kedua, pada siklus pembelajaran dengan model POGIL terdapat fase penemuan konsep atau pembentukan konsep. Pada fase penemuan konsep, siswa melakukan pelaporan hasil diskusi. Pada fase ini siswa bersama-sama dalam kelompoknya membuat kesimpulan mengenai penyelesaian yang diperoleh dan memaknai cara yang ditempuh dalam menyelesaikan masalah. Kemudian siswa dengan bimbingan guru mengorganisasikan datanya untuk menemukan keteraturan atau hubungan antar konsep. Oleh karena itu, dengan fase ini siswa dapat lebih memahami konsep IPA yang telah diperoleh. Hal ini sesuai dengan pendapat Hanson (2006) yang menyatakan bahwa fase eksplorasi dan penemuan konsep dalam siklus pembelajaran POGIL membantu siswa untuk mengembangkan pemahaman siswa terhadap konsep. Adanya pertukaran 
informasi, pemanfaatan ide anggota kelompok dan kerjasama akan membawa dampak yang positif terhadap semua anggota kelompok baik yang berkemampuan kurang maupun anggota kelompok yang berkemampuan lebih.

Ketiga, pada siklus pembelajaran dengan model POGIL terdapat fase aplikasi atau penerapan. Dalam fase ini siswa menerapkan pengetahuan barunya dalam latihan dan pemecahan masalah. Latihan dan pemecahan masalah akan memberikan kesempatan kepada siswa untuk membangun rasa percaya diri dalam suatu situasi sederhana dan konteks yang relevan dengan kehidupan sehari-hari. Kesempatan untuk mengimplementasikan konsep yang telah diperoleh dalam situasi baru dan konteks yang relevan dengan kehidupan sehari-hari akan membuat pengetahuan yang didapatkan siswa menjadi lebih bermakna. Yudiasminiati (dalam Sulatriningsih, 2013) menyatakan bahwa hasil belajar siswa akan lebih baik apabila siswa dapat menggunakan konsep yang telah dimilikinya untuk memecahkan hal serupa dalam kehidupan sehari-hari.

Keempat, konsep-konsep yang telah diperoleh siswa melalui pembelajaran POGIL diorganisasikan dengan membuat peta pikiran. Siswa menjadi lebih termotivasi dalam pembelajaran karena adanya pembuatan peta pikiran pada akhir pembelajaran. Hal ini didukung dengan pendapat Buzan (2007) bahwa peta pikiran lebih menarik dan merangsang daripada teknik mencatat tardisional. Dalam pembelajaran POGIL, peta pikiran dibuat pada akhir pembelajaran setelah siswa memperoleh informasi dan kemudian memvisualisasikan dalam bentuk peta pikiran yang menarik. Kegiatan ini membuat pengetahuan yang telah diperoleh melalui pembelajaran POGIL menjadi lebih terstruktur dan terorganisir sehingga daya ingat siswa terhadap materi pelajaran cenderung lebih lama. Hal ini sesuai dengan pendapat dari Wardani (2015) yang menyatakan bahwa membuat peta pikiran merupakan salah satu cara untuk mengasimilasikan konsep-konsep yang telah dipelajari oleh siswa.

Berbeda halnya dengan pembelajaran yang dilaksanakan di kelas kontrol yakni tidak menggunakan model POGIL berbantuan peta pikiran, siswa cenderung pasif dalam menggali pengetahuannya. Pembelajaran yang dilaksanakan masih berpusat pada guru (teacher centered). Guru mendominasi proses pembelajaran. Dalam pembelajaran tersebut guru bertugas untuk mengirimkan apa yang ketahui guru kepada siswa. Guru menjelaskan materi pembelajaran, melakukan tanya jawab kepada beberapa siswa yang dianggap sudah mengerti, kemudian memberikan tugas kepada siswa untuk diberikan nilai. Hal ini membuat siswa hanya mendengarkan kemudian mencatat dengan teknik tradisional tentang apa yang disampaikan oleh guru tanpa berupaya untuk menemukan sendiri konsep-konsep yang dipelajari.

Hasil penelitian ini sejalan dengan hasil penelitian yang dilakukan oleh Lestari (2016) pada siswa kelas V SD di Gugus I Kecamatan Gianyar menyatakan bahwa terdapat perbedaan yang signifikan hasil belajar IPA antara siswa yang dibelajarkan dengan model POGIL dan siswa yang dibelajarkan dengan model konvensional. Rata-rata skor hasil belajar pada kelompok siswa yang dibelajarkan dengan menggunakan model POGIL adalah 23,36 sedangkan rata-rata skor hasil belajar pada kelompok siswa yang dibelajarkan dengan menggunakan model konvensional adalah 17,23.

Selain itu, hasil penelitian yang dilakukan oleh Sari, dkk (2015) pada siswa kelas XI di SMA Negeri 1 Kartasura menyatakan bahwa ada perbedaan hasil belajar siswa yang dibelajarkan dengan menggunakan model POGIL dengan siswa yang dibelajarkan dengan model POGIL disertai mind mapping. Nilai rata-rata hasil belajar kognitif siswa yang dibelajarkan dengan model POGIL disertai mind mapping lebih tinggi dari siswa yang dibelajarkan dengan model POGIL tanpa disertai mind mapping. Nilai rata-rata hasil belajar kognitif siswa yang dibelajarkan dengan model POGIL disertai mind mapping sebesar 81,6 sedangkan siswa yang dibelajarkan dengan model POGIL tanpa disertai mind mapping sebesar 73,2.

\section{Simpulan dan Saran}

Berdasarkan hasil penelitian, dapat disimpulkan bahwa terdapat perbedaan yang signifikan hasil belajar IPA antara kelompok siswa yang dibelajarkan dengan model pembelajaran POGIL berbantuan peta pikiran dan kelompok siswa yang tidak dibelajarkan dengan model pembelajaran POGIL berbantuan peta pikiran pada siswa kelas V SD di Gugus II Kecamatan Banjar Tahun Pelajaran 2016/2017. Rata-rata hasil belajar IPA siswa setelah diberikan perlakuan model pembelajaran POGIL berbantuan peta pikiran yaitu 25,21 berada pada kategori sangat tinggi. Rata-rata hasil belajar IPA siswa yang tidak diberikan perlakuan model pembelajaran POGIL berbantuan peta pikiran yaitu 18,58 berada pada kategori tinggi. Dengan demikian model pembelajaran POGIL berbantuan peta pikiran berpengaruh terhadap hasil belajar IPA siswa kelas V SD, di Gugus II Kecamatan Banjar Tahun Pelajaran 2016/2017.

Saran yang dapat disampaikan berdasarkan penelitian yang telah dilakukan yaitu kepada guru disarankan untuk menerapkan model pembelajaran POGIL dengan peta pikiran dalam rangka memperbaiki kualitas pembelajaran di kelas dan mengembangkan hasil belajar IPA siswa. Hal ini karena dalam model pembelajaran POGIL dengan peta pikiran akan membantu siswa dalam memecahkan masalah dengan prosedur-prosedur penemuan dalam ilmu pengetahuan serta mendapat catatan yang menarik sehingga 
membantu siswa lebih mudah mengingat serta memahami materi yang sedang dipelajari. Guru juga sebaiknya membiasakan siswa untuk membuat peta pikiran tidak terbatas pada mata pelajaran IPA saja tetapi juga pada mata pelajaran lainnya. Selain itu, guru sebaiknya lebih sering membentuk kelompok diskusi dalam setiap pembelajaran, agar peserta didik terbiasa memecahkan permasalahan maupun soal-soal yang berkaitan dengan materi melalui diskusi dengan berkelompok.

Kepada siswa disarankan untuk berlatih membuat peta pikiran yang digunakan sebagai media untuk mempermudah siswa dalam menemukan konsep-konsep IPA secara mandiri, aktif dan kreatif untuk dapat meningkatkan kemampuan pemahaman konsep sehingga akan berimplikasi pada pencapaian hasil belajar yang lebih optimal. Penelitian ini terbatas membahas pada materi IPA yaitu tentang sifat-sifat cahaya dan batuan, melibatkan sampel terbatas pada satu gugus, dan mengukur satu variabel yaitu hasil belajar IPA. Kepada peneliti lain, disarankan agar mengadakan penelitian lebih lanjut tentang model pembelajaran POGIL dengan peta pikiran dalam bidang ilmu IPA maupun bidang ilmu lainnya. Pada materi-materi IPA yang lain dan lebih luas, melibatkan sampel yang lebih besar misalnya dalam satu kecamatan atau satu kabupaten serta melibatkan variabel-variabel yang lain sehingga mendapatkan hasil yang lebih optimal.

\section{Daftar Pustaka}

Anam, Khoirul. 2016. Pembelajaran Berbasis Inkuiri Metode dan Aplikasi. Cetakan Ke-2. Yogyakarta: Pustaka Pelajar.

Barthlow, Michele J. dan Scott B. Watson. 2011. "The Effectiveness of Process-Oriented Guided Inquiry Learning to Reduce Alternatif Conceptions in Secondary Chemistry". School Science and Mathematics. Volume 114. Nomor 5. (Halaman 246-255).

Brickman, Peggy. 2009. "Effect of Inquiry-based Learning on Students' Science Literacy Skills and Confidence”. International Journal Scholarship of Teaching and Learning. Volume 3. Nomor 2.

Buzan, Tony. 2007. Buku Pintar Mind Map untuk Anak. Jakarta: PT Gramedia Pustaka Utama.

Hale, Dena dan Linda Greef Mullen. 2009. "Designing Process-Oriented Guided-Inquiry Activities: A New Innovation for Marketing Classes". Marketing Education Review. Volume 19. Nomor 1. (Halaman 7480).

Hanson, David M. 2006. Instructor's Guide to Process-Oriented Guided-Inquiry Learning. Lisle, IL: Pacific Crest.

Kemdikbud. 2014. "Pendidikan Indonesia Gawat Darurat". Tersedia pada http://www.kemdikbud.go.id/kemdikbud/node/3571 (diakses tanggal 30 Desember 2016).

------. 2016. "Peringkat dan Capaian PISA Indonesia Mengalami Peningkatan". Tersedia pada: http://www.kemdikbud.go.id/main/blog/2016/12 /peringkat-dan-capaian-pisa-indonesia-mengalamipeningkatan (diakses tanggal 30 Desember 2016).

Lestari, Desak Putu Sri. 2016. "Pengaruh Model POGIL dan Minat Belajar Terhadap Hasil Belajar IPA pada Siswa Kelas V SD”. E-journal Mimbar PGSD Universitas Pendidikan Ganesha. Volume 4. Nomor 1.

Santyasa, I. W. 2005. Belajar dan Pembelajaran. Singaraja: IKIP Undiksha.

Sari, S. D. C. dkk. 2015. "Pengaruh POGIL (Process Oriented Guided Inquiry Learning) Disertai Mind Mapping terhadap Hasil Belajar Siswa pada Materi Asam Basa". Program Studi Biologi, Fakultas Biologi, Universitas Kristen Satya Wacana.

Simonson, S. R. dan Susan E. S. 2013. "Implementing POGIL in Undergraduate Biomechanics: Lessons Learned by A Novice". Journal of STEM Education. Volume 14 (Halaman 56 - 63).

Susanto, Ahmad. 2014. Teori Belajar dan Pembelajaran di Sekolah Dasar. Cetakan Ke-2. Jakarta: Prenadamedia Group.

Trianto. 2007. Model-model Pembelajaran Inovatif Berorientasi Konstruktivistik. Cetakan Ke-1. Jakarta: Prestasi Pustaka.

Wardani, T.Y.P. 2015. "Pengaruh Model Heuristik Vee dengan Peta Pikiran terhadap Hasil Belajar IPA Siswa Kelas V SD”. E-journal Mimbar PGSD Universitas Pendidikan Ganesha. Volume 3. Nomor 1.

Warsono dan Hariyanto. 2014. Pembelajaran Aktif Teori dan Asesmen. Cetakan Ke-3. Bandung: PT Remaja Rosdakarya.

Wiratma, I.G.L. 2010. "Politik Pendidikan dalam Pengembangan Kesadaran Kritis dan Jati Diri”. Jurnal IKA. Volume 8. Nomor 2. (Halaman 107-122 